\title{
Effect of Leech Therapy in Non Healing Ulcer WSR to Dustavruna an Observational Study
}

\author{
Chaturvedi Sonal 'Katara Pankaj" \\ "BAMS MS(Ay.) Medical Officer Department of Shalya Tantra (Surgery) \\ Ch. BrahmPrakashAyurvedCharakSansthanKheraDabar New Delhi-73, \\ ${ }^{* *}$ BAMS MD(Ay.) Assistant Professor PanchkarmakaDepartment, Ch. \\ BrahmPrakashAyurvedCharakSansthanKheraDabar Govt. of NCT Delhi N.D.-73,
}

\begin{abstract}
Wound or Vrana is a vague term which defined as a break in continuity of covering epithelium, skin or mucous membrane this observational study has been carried out in Ch.BrahmprakashayurvedcharakSansthanKheraDabar New Delhi-73. In this study 30 patients were observed during routine treatment. They were divided into 2 groups of 15-15 patients. In this study authors has try to treat the various type of wound by VranaShodhan-RopanaUpkrama along with leech therapy. Various investigative methodologies were adopted to confirm diagnosis of wound. This study was conducted into two groups of 15 patients. In group I, fifteen patients were treated with powder of Panchnimba Choorna,BrihatManjisthadiKwath (freshly prepare), VranaPrakkshalana(splashing) with PachvalkalKwath (freshly prepare), and dressing with Jatyadi oil, as described in Ayurveda texts like SushrutaSamhita and SharngdharSmhita and in group II, fifteen patients were treated with above mentioned treatment along with Jalokaavcharan(leech therapy). Results in group II were highly significant compare to Group I were significant.
\end{abstract}

KeyWord:Vrana,Jalaukaavcharana,Brihatmanjisthadikwath,Panchnimbachoorna,PanchvalkallKwath .Jatyadi Tail.

\section{Introduction:}

Ayurveda says Vrana is so called by the wise, since it covers (occupies the skin or the area of the body) and also because the VranaVastu (scar or cicatrix formed later) does not get lost or disappear even after healing and remains till the body survives. ${ }^{1}$ Vrana or wound is a vague term which defined as- a break in the continuity of covering epithelium, skin or mucousmembrane. ${ }^{2}$ It may either follow molecular death of surface epithelium or its traumatic removal. Skin ,Muscles, Vein ,Ligament,Bone, Bony joint, Kostha(abdominal viscera) and Vital organ these eight are the VranaVastu(dwelling seat of wound) in these all kind of wounds happens. ${ }^{3}$ That which happens in the first seat (skin)and causing tear in the skin only is easily treatable;while the remaining kinds (residing in other tissues )and bursting by themselves are treatable with difficulty. ${ }^{4}$ All kinds of wounds heal quickly in persons who are disciplined (use only healthy food and behave as directed by the physician) and treated by a good physician ; in those who are not disciplined and treated by ignorant physician, lead to great abnormality, because of great increase of the dosas ${ }^{5}$ it convert into DustaVrana or nonhealing ulcer.

DustaVruna Lakshan ${ }^{6}$ Greatly covered (slightly exposed) or greatly exposed, very hard or very soft, greatly elevated or depressed, very cold or very warm, terrified, filled with putrefying pus blood, muscles, veins, ligament, etc. wound raised up, having unpleasant look and smell accompanied with severe pain, burning, suppuration,erythema, itching, induration and such other complication greatly exuding vitiated blood and persisting for long time - thease are the symptom of dusta vrana. ${ }^{6}$

Wound can be classified into two type one is clinical and another is pathological, clinically wound is classified as spreading, healing,callous or chronic type and pathologically it can divided into nonspecific specific and malignant. In nonspecific ulcer, there can be amechanical, physical or chemical trauma. In specific ulcer can be arterial ulcer due to atherosclerosis, thrombo-angitis-oblitrance (Rraynaud's and burger's disease), and can be venous ulcer due to varicosity or DVT [deep vein thrombosis], it can be neurogenic or trophic ulcer eg. bed sore or perforating ulcer,tropical ulcer, diabetic ulcer, due to gouty deposit, hypertensive ulcer, ulcer duo to tuberculosis, syphilis, fungal infection,eczematous ulcer psoriatic ulcer etc. ${ }^{7}$

\section{Aims And Objective:}

This observationalstudy was conducted to assess the efficacy and safety of vranaUpkrama with palliative medicine and Raktamokshan by leech therapy in the disease of Vruna (wound)

\section{Selection of patient:}


30 patients of wound were randomly observed from OPD and IPD of Ch. Brahm Prakash Ayurved Charak Sansthan, KheraDabar, New Delhi -73 with irrespective of sex, age, occupation, religion etc. ). Out of which , five patients were leaved treatment in between study.

\section{Inclusion Criteria:}

1. Patient having clinical symptoms and sign of wound like Ulceration, Pain, Discharge, Erythema, inflammation.

2. Wounds such as - arterial ulcer, venous ulcer, diabetic ulcer, bed sore, eczematous ulcer ulcer due to Fungal infection, psoriatic ulcer, ulcer with DVT are included..

\section{Exclusion Criteria:}

1) Less than 5 year and more than 80 year patients were excluded.

2) HIV, HBsAg reactive patients were excluded.

3) Highly immune compromised patients and patients having chemotherapy, radiotherapyand patients on steroid therapy were excluded.

4) Patients having malignant changes in ulcer and severe deliberated patients were excluded.

\section{Diagnostic Criteria:}

1) By clinical signs and symptom of wound and which isthe root cause of wound formation.

2) laboratory investigation ${ }^{8}$ :

I. Blood routine[CBC,ESR,CT,BT, ,BLOOD SUGER,LIPID PROFILE, SERUM URIC ACID, CRP,RA FECTOR, ASO TITRE, HIV,HBsAG.

II. Bacteriological examination of discharge- it is particularly important in inflamed and spreading ulcer. If fungal infection is suspected fungal culture may be ouderd with discharge culture. This will not only give a clue as to the type of organism present in the ulcer, but also its sensitivity to a particular antibiotic. Discharge from tuberculosis ulcer will show acid fast bacilli.

III. Skin test: Monteux test is more important in children to diagnose tubercular ulcer and in adult to excluded tubercular ulcer.

IV. Chest X-Ray- to T.B ulcer to detect primary focus in the lung. It is important to exclude metastatic deposit in lungs in case of malignant ulcer.

V. Biopsy: it's very important in case of suspection of malignant ulcer. The biopsy is generally taken from the edge of ulcer taking a portion of surrounding healthy tissue. Biopsy material is then sent for histopathological examination.

VI. X-ray of bone and joint- to rule out Rheumatoid Arthritis, Gout, Osteo Arthrits and osteomyelitic changes in bone.

VII. Color dopplar U.S.G for Arterial and venous disease

VIII. Contrast radiography- Arteriography/ venography may be helpful to diagnose arterial or venous ulcer or deep vein thrombosis.

IX. Imaging technique: radioactive fibrinogen test using 25I labeled fibrinogen is quite accurate $90 \%$ in detecting deep vein thrombosis particularly in its formation stage.

X. Technetium99 clearance was used to know the blood flow of calf muscles.

\section{Grouping of patient:}

Observed patients were dividing into two therapeutic groups. Each group contained 15patients (group I and group II)

\section{Group I :}

In this group 15 patients were kept on Shaman Aushadha(palliative treatment) with locally Vranashodhana and Ropana management.

Shaman Aushadhi( palliative treatment) contains;

1) BrihatManjisthadi kwath $^{9}-30 \mathrm{ml}$ Twice daily.

2) Panchnimbi choorn ${ }^{10}-5 \mathrm{gm}$ Twice daily with luek warm water

3) Wound management--wound splacing with PanchvalkalKwath ${ }^{11}$,Wound dressing with Jatyaditail ${ }^{12}$ Duration--- up to 3 months and 2 months follow up period

Group B ; above mentioned management + Leech therapy (Jaloukavchuran)

Leech Therapy-12-20 sitting of leech therapy up to three months.

\section{Assessment Criteria}

Total assessment of therapy was done on the basis of relief in the sign and symptoms of disease as well as objective criteria (Based on ref.13) 


\begin{tabular}{|c|c|}
\hline 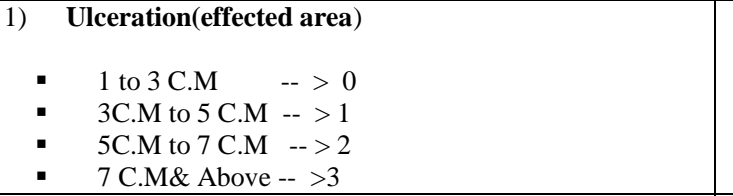 & $\begin{array}{ll}\text { 2) } & \text { Pain : } \\
\text { - } & \text { No pain at all-- } 0 \\
\text { - } & \text { Mild pain }---1 \\
\text { - } & \text { Mild to moderate pain--- } 2 \\
& \text { Moderate to severe pain with disturved sleep----3 }\end{array}$ \\
\hline $\begin{array}{l}\text { 3) Itching: } \\
\text { - } \quad \text { No itching--- } 0 \\
\text { - } \quad \text { Mild itching--- } 1 \\
\text { - } \quad \text { Moderate itching--- } 2 \\
\text { - } \quad \text { Severe itching that disturved sleep --3 }\end{array}$ & $\begin{array}{l}\text { 4) Discharge and slough: } \\
\text { - No discharge---0 } \\
\text { - Scanty discharge with no slough---1 } \\
\text { - Moderate discharge with mild slough-2 } \\
\text { - Massive discharge with offensive odour with excessive } \\
\text { slough formation--3 }\end{array}$ \\
\hline $\begin{array}{l}\text { 5) } \quad \text { Erythema and marginal induration: } \\
\text { - } \quad \text { No erythema no marginal induration---0 } \\
\text { - } \quad \text { Mild erythema with mild marginal induration---1 } \\
\text { - } \quad \text { Moderate erythema with moderate marginal induration---2 } \\
\text { - } \quad \text { Severe erythema with marginal induration---3 }\end{array}$ & \\
\hline
\end{tabular}

Overall Assessment of Therapy: Table -01

\begin{tabular}{|c|c|c|}
\hline $25-50 \%$ & Relief & Minor improvement \\
\hline $50-75 \%$ & Relief & Moderate Improvement \\
\hline $100 \%$ & Relief & Complete remission. \\
\hline
\end{tabular}

\section{Results:}

Clinical result of this observational study are as follows;-

Table - 02 Effect On Sign \& Symptoms Of 12 Patients Of Group 1 :

\begin{tabular}{|c|c|c|c|c|c|c|c|c|}
\hline \multirow[t]{2}{*}{ Symptoms } & \multicolumn{2}{|c|}{ Mean Score } & \multirow{2}{*}{$\begin{array}{c}\% \\
\text { Relief }\end{array}$} & \multirow[t]{2}{*}{ Mean } & \multirow[t]{2}{*}{ S.D. $\square$} & \multirow[t]{2}{*}{ S.E. $\square$} & \multirow[t]{2}{*}{$\mathbf{t}$} & \multirow[t]{2}{*}{$\mathbf{P}$} \\
\hline & B.T. & A.T. & & & & & & \\
\hline $\begin{array}{l}\text { Ulceration(Effected } \\
\text { area) }\end{array}$ & 1.23 & 0.38 & 68.29 & .84 & 0.22 & 0.22 & 3.81 & $<0.01$ \\
\hline Pain & 0.91 & 0.50 & 45.05 & 0.41 & 0.66 & 0.18 & 2.27 & $<0.05$ \\
\hline Itching & 2.08 & 0.83 & 60.09 & 1.25 & 0.75 & 0.22 & 5.68 & $<0.001$ \\
\hline Discharge and Slough & 1.50 & 0.67 & 55.33 & 0.83 & 0.57 & 0.16 & 5.18 & $<0.001$ \\
\hline $\begin{array}{l}\text { Erythema and } \\
\text { Marginal induration }\end{array}$ & 2.36 & 1.79 & 24.15 & 0.57 & 0.53 & 0.20 & 2.83 & $<0.05$ \\
\hline
\end{tabular}

Table - 03, Effect on signs \& symptoms of 13 patients of Group 2 :

\begin{tabular}{|c|c|c|c|c|c|c|c|c|}
\hline \multirow[t]{2}{*}{ Symptoms } & \multicolumn{2}{|c|}{ Mean Score } & \multirow{2}{*}{$\begin{array}{c}\% \\
\text { Relief }\end{array}$} & \multirow[t]{2}{*}{ Mean } & \multirow[t]{2}{*}{ S.D. $\square$} & \multirow[t]{2}{*}{ S.E. $\square$} & \multirow[t]{2}{*}{$\mathbf{t}$} & \multirow[t]{2}{*}{$\mathbf{p}$} \\
\hline & B.T. & A.T. & & & & & & \\
\hline $\begin{array}{l}\text { Ulceration } \\
\text { (Effected area) }\end{array}$ & 1.33 & 0.33 & 75.80 & 1.00 & 0.85 & 0.25 & 4.00 & $<0.01$ \\
\hline Pain & 1.61 & 0.23 & 85.71 & 1.38 & 0.96 & 0.26 & 5.30 & $<0.001$ \\
\hline Itching & 0.53 & 0.20 & 56.60 & 0.30 & 0.48 & 0.13 & 2.30 & $<0.05$ \\
\hline $\begin{array}{l}\text { Discharge and } \\
\text { Slough }\end{array}$ & 2.32 & 0.82 & 64.65 & 1.50 & 0.79 & 0.23 & 6.52 & $<0.001$ \\
\hline $\begin{array}{l}\text { Erythema and } \\
\text { Marginal } \\
\text { induration }\end{array}$ & 1.69 & 0.61 & 63.90 & 1.08 & 0.51 & 0.15 & 7.20 & $<0.001$ \\
\hline
\end{tabular}

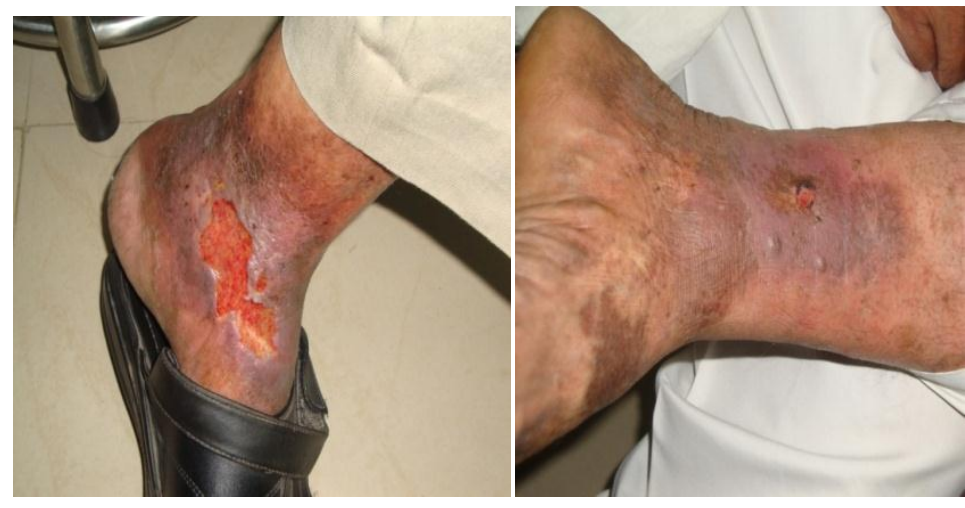




\section{BEFORE TREATMENT AFTER TREATMENT Group II results are highly significant then group I}

\section{Discussion:}

Panchnimba choorna having Rasayan and antimicrobial properties which are act on all type of TwakVikar(skin diseases) ${ }^{10}$ Nimbidin is a mixture of tetranortriteropenes and is the major active principle of seed oil of Azadirachta Indica, ${ }^{14}$ It protects the skin from damaging effects of . it is suitable for use in anti ageing sunscreen and general purpose of skin care. It have ability to immune response system.

Jatyadi tail having properties of wound healing specialy in Nadivrana(Sinus) ,burn ulcer,kustha(skin disease),Aagantuj (Acquired) vrana and Doshaj (Pathological) vrana. ${ }^{12}$

The drug contained inBrihatManjisthadikwath are having wound healing propertiesAnthraquinones a chief phytochemical present in many species of the Rubiaceae family exhibit antimicrobial,antifungal, hypotensive, analgesic, antimalarial, antioxidant, antileukemic and functions. Rubiacordifolia is used to treat skin infections ${ }^{15}$.

Drugs of PanchvalkalKwath having property of VrauhaShodhan and Ropana activity by their active principles. ${ }^{11}$

Medicinal leeches have been found to secrete saliva containing about 60 different proteins. These achieve a wide variety of goals useful to the leech as it feeds, helping to keep the blood in liquid form and increasing blood flow in the affected area. Several of these secreted proteins serve as anticoagulants (such as hirudin), platelet aggregation inhibitors (most notably apyrase,collagenase, and calin), vasodilators, and proteinase inhibitors. It is also thought that the saliva contains an anesthetic, as leech bites are generally not painful. The secret to the leeches power is what lies in it's bite. Within the salivary gland secretion of the leech contains over 60 bioactive substances, the most powerful and well know being "Hirudin". It is a powerful anticoagulant or blood thinner which thins the blood, it is famous for improving the cardiovascular system among other benefits. The leeches are able to suck out stagnant pooling blood from areas where the vessels that bring blood back to the heart were not reattached, while the salivary secretions helped re-form the microcirculation. other well known substances include enzymes which restore microcirculation, have antiinflammatory and antibiotic effects, vasodilators, pain killers and seritonin (the happy hormone).Leech therapists say that once a leech tastes a person's blood, it makes a map of the problems in the body and adjusts the salivary secretion accordingly. ${ }^{15}$

Acharya Sushruta have also mentioned about use of leech therapy in Dusta Vran(non healing ulcer). ${ }^{16}$

\section{Conclusion:}

Leech therapy along with herbal medicine (oral and locally) which were given to patient having property of anti proliferative anti inflammatory, anti histaminic antibacterial, immune modulator, anxiolytic, blood purificatory activity as Neem having nimbidin as active principle which suppresses function of macrophages and neutrophils, relevance to its anti inflammatory mechanism, antibacterial action and anti proliferative action.

This is a observational data so this study may performed in larger group of patients in future.

\section{Refrances:}

[1] IllustatedSusrutaSamhita (Text, English Translation,Notes,Appendeces and Index) VOL.1- Sutra Sthana , VranaprashnaAdhyaya 21/40 Edited by Prof.K.R.Srikant Murthy ChaukhambhaOrientaliaVaranassi Reprint Edition 2012, pg.no.164.

[2] A manual on Clinical Surgery by S . Das , $6^{\text {th }}$ Edition,Chapter 4, pg no.45

[3] IllustatedSusrutaSamhita (Text, English Translation,Notes,Appendeces and Index) VOL.1- Sutra Sthana , VranasravaAdhyaya 22/3 Edited by Prof.K.R.Srikant Murthy ChaukhambhaOrientaliaVaranassi Reprint Edition 2012, pg.no.165.

[4] IllustatedSusrutaSamhita (Text, English Translation,Notes,Appendeces and Index) VOL.1- Sutra Sthana, VranasravaAdhyaya 22/4 Edited by Prof.K.R.Srikant Murthy ChaukhambhaOrientaliaVaranassi Reprint Edition 2012,pg.no.165.

[5] IllustatedSusrutaSamhita (Text, English Translation,Notes,Appendeces and Index) VOL.1- Sutra Sthana , VranasravaAdhyaya 22/6 Edited by Prof.K.R.Srikant Murthy ChaukhambhaOrientaliaVaranassi Reprint Edition 2012, pg.no.165.

[6] IllustatedSusrutaSamhita (Text, English Translation,Notes,Appendeces and Index) VOL.1- Sutra Sthana , VranaprashnaAdhyaya 22/7 Edited by Prof.K.R.Srikant Murthy ChaukhambhaOrientaliaVaranassi Reprint Edition 2012, pg.no.166

[7] A manual on Clinical Surgery by $S$. Das , $6^{\text {th }}$ Edition, Chapter 4, pg no.45

[8] A manual on Clinical Surgery by S . Das , $6^{\text {th }}$ Edition,Chapter 4 , pg no. 50

[9] Sarangadharasamhita( Dipika Hindi Commentary by Dr. BrahmanandTripathi, ChaukhambaSurbhartiPrakashan) MadhyamKhand Chapter-2,137 to 142 , pg no. 154 .

[10] Sarangadharasamhita ( Dipika Hindi Commentary by Dr. BrahmanandTripathi, ChaukhambaSurbhartiPrakashan) MadhyamKhand Chapter- 6,150 to 155 , pg no. 192

[11] Sarangadharasamhita( Dipika Hindi Commentary by Dr. BrahmanandTripathi, ChaukhambaSurbhartiPrakashan) MadhyamKhand Chapter-2,149,

[12] Sarangadharasamhita( Dipika Hindi Commentary by Dr. BrahmanandTripathi, ChaukhambaSurbhartiPrakashan) MadhyamKhand Chapter-9,168 to 171 , pg no. 242 . 
[13] Third Edition of SRB'S Mannual of surgery by SriramBhat M Forward PrakashRao Chapter -Ulcer pg. no. 17 ( JAYPEE Publication)

[14] Nimbidin http//www.ncbi.nlm.nih.gov/pubmed/15174005(nimbidin) browsed on 27/09/2013, 15;30;23

[15] www. shelf3d.com/i/Hirudo\%20medicinalis \&http://www.scribd.com/doc/60006382/Phytochemistry-andImmunopharmacological-R-Cordifolia browsed on 27/09/2013, 15:55:45Mhttp//www.hirudoleeches.com browsed on 15/01/2014 ; timed 05:17:34

[16] IllustatedSusrutaSamhita (Text, English Translation,Notes,Appendeces and Index) VOL.1 I- Chikitsa Sthana, Dvivraniya Chikitsa Adhyaya 01/27-29, Edited by Prof.K.R.Srikant Murthy ChaukhambhaOrientaliaVaranassi Reprint Edition 2012 , pg.no.11 